\title{
OPEN Exploring the potential of moringa leaf extract as bio stimulant for improving yield and quality of black cumin oil
}

\author{
Abid Mehmood ${ }^{1,14 凶}$, Khalid Naveed ${ }^{1}$, Qasim Ayub $^{2}$, Saud Alamri ${ }^{3}$, Manzer H. Siddiqui', \\ Chao $\mathrm{Wu}^{4}$, Depeng Wang ${ }^{5}$, Shah Saud ${ }^{5,6 \bowtie}$, Jan Banout ${ }^{6}$, Subhan Danish ${ }^{7}$, Rahul Datta ${ }^{8}$, \\ Hafiz Mohkum Hammad ${ }^{9}$, Wajid Nasim ${ }^{10}$, Muhammad Mubeen ${ }^{11}$, Farooq Shah ${ }^{12}$ \& \\ Shah Fahad ${ }^{1,13,14 \bowtie}$
}

The history of plants to be utilized as medicines is thousands of years old. Black cumin is one of the most widely examined plant possessing naturally occurring compounds with antimicrobial potential. Foliar application of growth stimulators is a successful strategy to enhance yield and quality in many crops. A field study was planned to apply growth stimulator like moringa leaf extract on black cumin crop grown under field conditions using RCB design with three replications. All other agronomic inputs and practices were uniform. The treatments were moringa leaf extract concentrations $(10 \%$, $20 \%$ ), growth stages (40 days after sowing, 80 DAS, 120 DAS, $40+80$ DAS, $40+120$ DAS, $80+120$ DAS, $40+80+120$ days after sowing) and two controls unsprayed check (i.e. no moringa leaf extract, no water) and sprayed check (no moringa leaf extract + water). Application of $20 \%$ moringa leaf extract at stage-7 $(40+80+120$ days after sowing) had significantly increased plant height, branches plant $^{-1}$, essential oil content, fixed oil content, peroxidase value and iodine value of black cumin oil over unsprayed control. Application of moringa leaf extract showed maximum results and improves growth and yield of black cumin when applied at $40+80+120$ days after sowing. As this study was only conducted using moringa leaf extract, it is advisable to conduct an experiment with various bio stimulants along with fertilizer combinations and growth regulators to check their synergistic effects for more reliable and acceptable recommendations in future.

Black cumin (Nigella sativa L.) also known as Kalonji locally, is one of the most widely examined plant possessing naturally occurring compounds with anti-cancer potential. Black cumin is a filed crop of family Ranunculaceae also known as butter cup family ${ }^{1}$. Its seeds are similar in appearance to onion seeds and used for medicine or for flavoring foods ${ }^{2}$. It is originated from Mediterranean region and spread to Asia, Africa and Europe ${ }^{3}$. The numerous vernacular names indicate the use of the spice in more than 100 countries. Nigella seeds are being utilized as

\footnotetext{
${ }^{1}$ Department of Agronomy, The University of Haripur, Haripur 22620, Khyber Pakhtunkhwa, Pakistan. ${ }^{2}$ Department of Horticulture, The University of Haripur, Haripur 22620, Khyber Pakhtunkhwa, Pakistan. ${ }^{3}$ Department of Botany and Microbiology, College of Science, King Saud University, Riyadh 11451, Saudi Arabia. ${ }^{4}$ Guangxi Key Laboratory of Functional Phytochemicals Research and Utilization, Guangxi Institute of Botany, Guangxi Zhuang Autonomous Region and Chinese Academy of Sciences, Guilin 541006, China. ${ }^{5}$ College of Life Science, Linyi University, Linyi 276000, Shandong, China. ${ }^{6}$ Faculty of Tropical AgriSciences, Czech University of Life Sciences Prague, Prague, Czech Republic. ${ }^{7}$ Department of Soil Science, Faculty of Agricultural Sciences and Technology, Bahauddin Zakariya University, Multan 60800, Pakistan. ${ }^{8}$ Department of Geology and Pedology, Faculty of Forestry and Wood Technology, Mendel University in Brno, 61300 Brno, Czech Republic. ${ }^{9}$ Department of Agronomy, Muhammad Nawaz Sharif University of Agriculture, Multan 66000, Pakistan. ${ }^{10}$ Department of Agronomy, University College of Agriculture and Environmental Sciences, IUB, Bahawalpur, Pakistan. ${ }^{11}$ Department of Environmental Sciences, COMSATS University Islamabad, Vehari Campus, Islamabad, Pakistan. ${ }^{12}$ Department of Agriculture, Abdul Wali Khan University Mardan, Khyber Pakhtunkhwa 23200, Pakistan. ${ }^{13}$ Hainan Key Laboratory for Sustainable Utilization of Tropical Bioresource, College of Tropical Crops, Hainan University, Haikou 570228, Hainan, China. ${ }^{14}$ Theses authors are contributed equally: Abid Mehmood and Shah Fahad. ${ }^{\boxplus}$ email: abidawan1990@ gmail.com; saudhort@gmail.com; shah_fahad80@yahoo.com
} 


\begin{tabular}{|c|c|c|c|c|}
\hline & Plant height $(\mathrm{cm})$ & Number of branches plant ${ }^{-1}$ & Fixed oil content $\left(\% \mathrm{vw}^{-1}\right)$ & $\begin{array}{l}\text { Essential oil content (\% } \\
\left.\mathrm{vw}^{-1}\right)\end{array}$ \\
\hline \multicolumn{5}{|l|}{ Growth stages } \\
\hline Stage 1 & 51.8 & 55.16 & 32.68 & 0.36 \\
\hline Stage 2 & 61.45 & 62.5 & 34.37 & 0.35 \\
\hline Stage 3 & 47.45 & 51.66 & 33.41 & 0.37 \\
\hline Stage 4 & 65.15 & 65.5 & 35.18 & 0.39 \\
\hline Stage 5 & 54.9 & 62 & 34.64 & 0.36 \\
\hline Stage 6 & 64.13 & 60.83 & 35.72 & 0.37 \\
\hline Stage 7 & 68.15 & 70.66 & 37.08 & 0.42 \\
\hline $\operatorname{LSD}(0.05)$ & 1.15 & 1.42 & 0.33 & 0.007 \\
\hline \multicolumn{5}{|l|}{ MLE concentrations } \\
\hline MLE@ @ 10\% & 58.83 & 60.19 & 34.06 & 0.37 \\
\hline MLE @ 20\% & 62.2 & 62.19 & 35.39 & 0.38 \\
\hline $\operatorname{LSD}(0.05)$ & 0.32 & 1.42 & 0.09 & 0.002 \\
\hline \multicolumn{5}{|c|}{ Control vs rest treatments } \\
\hline Control & 42.7 & 39 & 31.48 & 0.33 \\
\hline Rest treatments & 58.02 & 61.19 & 34.73 & 0.37 \\
\hline Significance & $* *$ & *** & $* *$ & ** \\
\hline \multicolumn{5}{|c|}{ Water only vs rest treatments } \\
\hline Water only & 44.2 & 40.33 & 33.29 & 0.34 \\
\hline Rest treatments & 58.02 & 61.19 & 34.73 & 0.37 \\
\hline Significance & $* *$ & $* *$ & $* *$ & ** \\
\hline Interaction & \multicolumn{4}{|l|}{ Significance } \\
\hline Stages $\times$ concentrations & NS & \begin{tabular}{|l|} 
Figure 1 \\
\end{tabular} & Figure 2 & NS \\
\hline
\end{tabular}

Table 1. Plant height $(\mathrm{cm})$, number of branches plant ${ }^{-1}$ fixed oil content $\left(\% \mathrm{vw}^{-1}\right)$ and essential oil content (\% $\mathrm{vw}^{-1}$ ) of black cumin as affected by moringa leaf extract applied at various growth stages. MLE moringa leaf extract, @ at the rate, \% percent, Stage 1 application of MLE at 40 DAS, S2=Application at 80 DAS, S3=120 DAS, S $4=40+80$ DAS, S5 $=40+120$ DAS, S6 $=80+120$ DAS, S7 $=40+80+120$ days after sowing, ${ }^{* *}$ highly significant, NS non-significant, LSD least significant difference.

a medicine and spice since the prehistoric time. Seeds have bitter and unpleasant taste so that the consumption of whole seed even in small quantity gives a feeling of constriction of throat ${ }^{4}$.

In Islam, black cumin is considered as the best healing medicine available. The Holy Prophet Muhammad (صَلَّى اللهُ عَلَيْهِه وَسَلَّمَ) once stated that "Kalonji can cure every disease except death". Due to its higher nutritional

values and medicinal importance it is also refereed as Seed of blessing (habbatul barakah) $)^{5}$. Medicinal value of black cumin is immense and numerous workers appreciated its unique, varied and powerful pharmacological traits. The medicinal importance of the herb is widely reported ${ }^{6}$. Oil of black cumin seeds is high in unsaturated fatty acids and can be predicted to have significant health benefits when consumed ${ }^{7}$. The most potent and fruitful medicinal properties lie in its volatile components ${ }^{8}$.

The production of black cumin in Pakistan has not been reported on commercial scale but it is widely used for various purposes in the country. A range of endogenous and external factors influence crop productivity and development. In addition, crop development is often influenced by a variety of biotic and abiotic stresses ${ }^{9,10}$.

Moringa is among one of its 13 species belongs to genus Moringa and family Moringnance. Moringa oils and leaves contains some most potent antioxidants and have higher concentrations of minerals like iron, calcium, phenolic acid and vitamins like vitamin A, C riboflavin and beta carotene ${ }^{11}$. The availability of mineral nutrients in moringa leaf might be used to complement the nutritional needs of horticulture crops, reducing the quantity of chemical fertilizer used. At very low or diluted concentrations, moringa leaf extract acts as a bio stimulant ${ }^{12}$. Moringa leaf extracts (MLE) are also have enhanced amounts of zeatin, which plants greener and imparts stress tolerance in plants ${ }^{13}$. Certain previous studies indicated the presence of many vital antioxidants in MLE but a very little information is available on activity of these antioxidants and mechanism which regulates the physiological process in black cumin crop.

\section{Results and discussion}

Plant height (cm). Plant height of black cumin as affected by moringa leaf extract applied at various growth stages is reported in Table 1. Both concentrations of moringa leaf extract significantly affected plant height of black cumin. All growth stages also showed statistically significant results. Mean comparison of control vs treatments and water spray vs rest were also found significant for plant height $(\mathrm{cm})$ of black cumin. Whereas, interaction of moringa leaf extract concentrations and growth stages remained non-significant. With increase in interval of spraying moringa leaf extract, plant height enhanced and thus taller plants $(68.15 \mathrm{~cm})$ were recorded when 


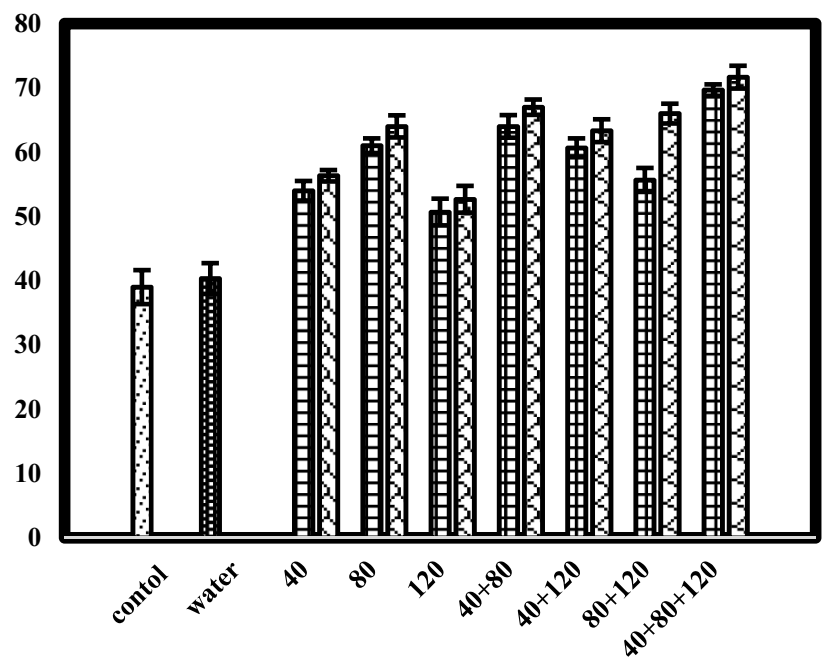

ㅁmle 10 四mle 20

Figure 1. Number of branches plant ${ }^{-1}$ of black cumin as affected by moringa leaf extract applied at various growth stages.

moringa leaf extract was sprayed at stage-7 $(40+80+120$ days after sowing), followed by $(65.15 \mathrm{~cm})$ stage -4 $(40+80$ days after sowing), while lower plants height $(47.45 \mathrm{~cm})$ was recorded in stage-3 (120 days after sowing). The use of moringa leaf extract during critical vegetative development phases increased the black cumin crop's plant height. Similar results were recorded by Abbas et al. ${ }^{14}$ that moringa leaf extract enhanced plant height and improved fresh and dried weight of wheat root when compared to control. Taller $(62.2 \mathrm{~cm})$ plants were recorded in $20 \%$ moringa leaf extract sprayed plots followed by $(55.8 \mathrm{~cm}) 10 \%$ moringa leaf extract. Spraying moringa leaf extract on a variety of field crops can boost plants and increase vegetative development ${ }^{15}$.

Branches plant ${ }^{-1}$. Branches plant ${ }^{-1}$ of black cumin were significantly influenced by moringa leaf extract concentrations, stage of application as well as their interaction (Table 1). The planned mean comparison of control vs rest and water spray vs rest were also found significant for branches plant ${ }^{-1}$. The unsprayed against sprayed treatments of moringa leaf extract showed that in unsprayed plots number of branches plant ${ }^{-1}(39)$ were less than plants sprayed with moringa leaf extract (61.19). Highest number of branches plant ${ }^{-1}(62.19)$ were observed $20 \%$ moringa leaf extract treated plots. These results are in agreement with Mahmood ${ }^{16}$ who found that foliar application of MLE contains an adequate amount of stimulating substances that promote cell division and enlargement at a faster rate. Zeatin, a growth hormone found in moringa leaf extract, encourages the growth of lateral buds, which leads to an increase in the number of branches. After pounding $100 \mathrm{~g}$ of Moringa leaves in $8 \mathrm{~L}$ of water, foliar spray of moringa leaf extract enhanced branches plant ${ }^{-1}$ in okra ${ }^{17}$. More number of branches plant $^{-1}$ (70.66) were attained in plots sprayed with moringa leaf extract at growth stage $7(40+80+120$ days after sowing), followed by growth stage $4(40+80$ days after sowing). The effect of the application of MLE at the rate of $20 \%$ at 40 days' interval increased the number of branches and this may be because of the abundant supply of macro and micronutrients and growth hormones. The result of yield parameters revealed that the yield increased as the frequency of moringa leaf extract increased. This is because hormone enhances formation and development of flowers and ripening of fruits. Hormones also enhance growth and yield by altering photosynthetic distributive pattern within the plants. The findings were also in line with that of Manzoor et al. ${ }^{18}$ who found that an aqueous extract of moringa significantly influence yield and yield components such as number of branches, number of fruits per plant and fruit weight of tomato. The significant interaction of MLE and growth stages is presented in Fig. 1. Applying moringa leaf extract @ 20\% at all growth stages enhanced branches plant $^{-1}$. Maximum branches plant ${ }^{-1}$ was observed when moringa leaf extract was sprayed @ 20\% at growth stage $7\left(40+80+120\right.$ days after sowing) whereas, minimum branches plant ${ }^{-1}$ was recorded in plants sprayed with $10 \%$ moringa leaf extract at growth stage-3 (120 days after sowing). Moringa leaf extract (MLE) increased number of branches. Similar results were recorded by Jain et al. ${ }^{19}$ ), who reported MLE positively enhanced plant growth attributes of wheat. He also stated that with increasing MLE concentration and application intervals, the growth parameters such as branches plant ${ }^{-1}$ were increased in arithmetic order. Plant growth regulators are essential for controlling growth and development of plants ${ }^{20}$. These plant growth regulators increased yield by changing the dry matter distribution pattern or controlling the growth characteristics in crop plants, depending on the dosage and time of application ${ }^{21}$. In comparison to control, foliar application of moringa leaf extract resulted in a markedly higher branches plant ${ }^{-1}$. The increased number of branches plant ${ }^{-1}$ might be due to Zeatin present in moringa leaf extract, which is very effective in delaying the abscission response $\mathrm{e}^{10}$. 


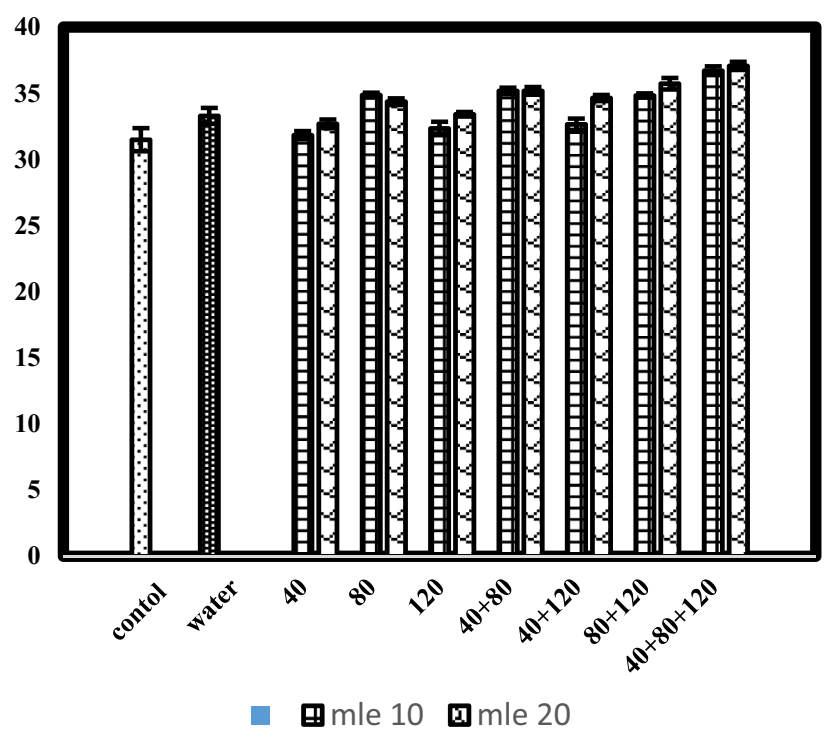

Figure 2. Fixed oil content (\%) of black cumin as affected by moringa leaf extract applied at various growth stages.

Fixed oil content $\left(\% \mathbf{v w}^{-1}\right)$. Data concerning fixed oil content $\left(\% \mathrm{vw}^{-1}\right)$ in response to moringa leaf extract applied at various growth stages is given in Table 1 and Fig. 2. Statistical analysis of data indicated that foliar application of various concentrations of moringa leaf extract, their stage of application and interaction of concentrations and growth stages had significantly affected fixed oil content $\left(\% \mathrm{vw}^{-1}\right)$ of black cumin crop. The planned mean comparison of control vs rest and water spray vs rest had significant effect on fixed oil content (\% $\mathrm{vw}^{-1}$ ). Highest fixed oil percentage (35.39\%) was recorded when moringa leaf extract was sprayed @ 20\%, followed by (34.06\%) 10\% moringa leaf extract, whereas, control (31.48\%) showed lowest fixed oil \%. Sakr et al. ${ }^{22}$ indicated that foliar applications of MLE significantly improved the oil percentage and yield plant ${ }^{-1}$ and feddan of geranium plants. Application of MLE at growth stage-7 $(40+80+120$ days after sowing) showed maximum fixed oil content percentage $(37.08 \%)$ as compared to all other growth stages. Minimum fixed oil percentage was recorded in growth stage-1 (40 days after sowing). Concerning the interaction of moringa leaf extract vs application stage, highest fix oil (37.45\%) was observed when moringa leaf extract @ 20\% was applied as foliar spray at growth stage-7 (40+80+120 days after sowing), followed by (36.71\%) moringa leaf extract @ 10\% applied at growth stage-7. Lowest fixed oil percentage (31.83\%) was observed in plants sprayed with $10 \%$ moringa leaf extract at stage 1 (40 days after sowing). According to Rady et al. ${ }^{23}$, biosynthesis of cytokinins promotes the movement of stem reserves to new shoots, resulting in stable plant development, the prevention of premature leaf senescence, and the preservation of more leaf area for photosynthetic action.

Essential oil content $\left(\% \mathbf{v w}^{-1}\right)$. Essential oil content $\left(\% \mathrm{vw}^{-1}\right)$ is a vital oil component of black cumin. Moringa leaf extract concentrations and stage of their application had significant effect on essential oil content of black cumin while the interaction remained non-significant (Table 1). Application of MLE at 20\% resulted in higher essential oil yield (0.38\%) followed by $10 \%$ moringa leaf extract (0.37) sprayed plots. Control plots resulted in lower essential oil ( $0.33 \%)$ content of black cumin. Many research ventures around the world are currently focusing on increasing the biomass yield and volatile oil output of aromatic plants. Moringa leaf extract has been discovered to be an excellent bio-stimulant for enhancing not only crop growth but also yield ${ }^{24,25}$. According to Aslam et al. ${ }^{26}$, Plant treated with MLE had major impacts, including an average rise in oil concentrations. Interestingly, MLE treatment not only increased the coriander fruit yield but also improved the fruits volatile oil suggesting that MLE could be a promise plant growth promoter that improved the content of volatile oil in coriander. MLE application also positively affected the volatile oil constituents (Table 2). Increasing the volatile oil in coriander by MLE could be due to the MLE components including amino acids, nutrient elements and phytohoromes that motivate the accumulation of secondary metabolites ${ }^{27}$. The phytohormones affect the pathway of terpenoids through motivating the responsible physiological and biochemical processes ${ }^{28}$. Concerning the application stages of moringa leaf extract, higher essential oil content \% of black cumin $(0.42 \%)$ was observed in growth stage- $7(40+80+120$ days after sowing), followed by $(0.39 \%)$ growth stage- $4(40+80$ days after sowing), whereas, lower essential oil content \% (0.36\%) of black cumin was observed in growth stage-1 (40 days after sowing). Plant growth regulators are essential for controlling the amount, type, and direction of plant growth, development, and yield ${ }^{20}$. These plant growth regulators increased yield by changing the dry matter distribution pattern or controlling the growth characteristics in crop plants, depending on the dosage and time of application ${ }^{21}$. Exogenous application of MLE resulted in higher yield and quality ${ }^{29}$.

Peroxidase value (meq $\mathrm{kg}^{-1}$ ). The response of MLE and stage of MLE application recorded for peroxidase value is stated in Table 2 . The data depicted that moringa leaf extract concentrations, stage of application 


\begin{tabular}{|c|c|c|c|c|}
\hline & Peroxidase value $\left(\mathrm{meq} \mathrm{kg}^{-1}\right)$ & Iodine value ( $\mathrm{g}$ of $\mathrm{I}_{2} / 100 \mathrm{~g}$ ) & Total phenolic & Total free amino acids \\
\hline \multicolumn{5}{|l|}{ Growth stages } \\
\hline Stage 1 & 6.3 & 82.83 & 69.25 & 314.16 \\
\hline Stage 2 & 6.02 & 84.52 & 73.85 & 323.23 \\
\hline Stage 3 & 6.12 & 84.57 & 55.25 & 290.31 \\
\hline Stage 4 & 5.73 & 86.95 & 63.46 & 355.93 \\
\hline Stage 5 & 6.22 & 83.67 & 71.38 & 323.23 \\
\hline Stage 6 & 6.39 & 85.61 & 76.66 & 345.45 \\
\hline Stage 7 & 6.42 & 87.35 & 81.23 & 364.28 \\
\hline $\operatorname{LSD}(0.05)$ & 0.077 & 0.25 & 0.82 & 3.2 \\
\hline \multicolumn{5}{|l|}{ MLE concentrations } \\
\hline MLE@ @ 10\% & 6.03 & 84.84 & 68.73 & 325.54 \\
\hline MLE @ 20\% & 6.30 & 85.3 & 71.59 & 336.34 \\
\hline $\operatorname{LSD}(0.05)$ & 0.011 & 0.072 & 0.23 & 0.91 \\
\hline \multicolumn{5}{|c|}{ Control vs rest treatments } \\
\hline Control & 5.43 & 78.28 & 50.66 & 265.96 \\
\hline Rest treatments & 6.171 & 85.0747619 & 69.19 & 327.16 \\
\hline Significance & $* *$ & $* *$ & $* *$ & $* *$ \\
\hline \multicolumn{5}{|c|}{ Water only vs rest treatments } \\
\hline Water only & 5.23 & 80.916666667 & 55.73 & 274.16 \\
\hline Rest treatments & 6.171 & 85.0747619 & 70.15 & 330.94 \\
\hline Significance & $* *$ & $* *$ & $* *$ & $* *$ \\
\hline Interaction & \multicolumn{4}{|l|}{ Significance } \\
\hline Stages $\times$ concentrations & Figure 3 & Figure 4 & NS & NS \\
\hline
\end{tabular}

Table 2. Peroxidase value ( $\mathrm{meq} \mathrm{kg}^{-1}$ ) and Iodine value ( $\mathrm{g}$ of $\mathrm{I}_{2} / 100 \mathrm{~g}$ ) of black cumin as affected by moringa leaf extract applied at various growth stages. MLE moringa leaf extract, @ at the rate, \% percent, Stage 1 application of MLE at $40 \mathrm{DAS}, \mathrm{S} 2=$ Application at $80 \mathrm{DAS}, \mathrm{S} 3=120 \mathrm{DAS}, \mathrm{S} 4=40+80 \mathrm{DAS}, \mathrm{S} 5=40+120$ DAS, S6 $=80+120$ DAS, S7 $=40+80+120$ Days after sowing, ${ }^{* \star}$ highly significant, $N S$ non-significant, $L S D$ least significant difference.

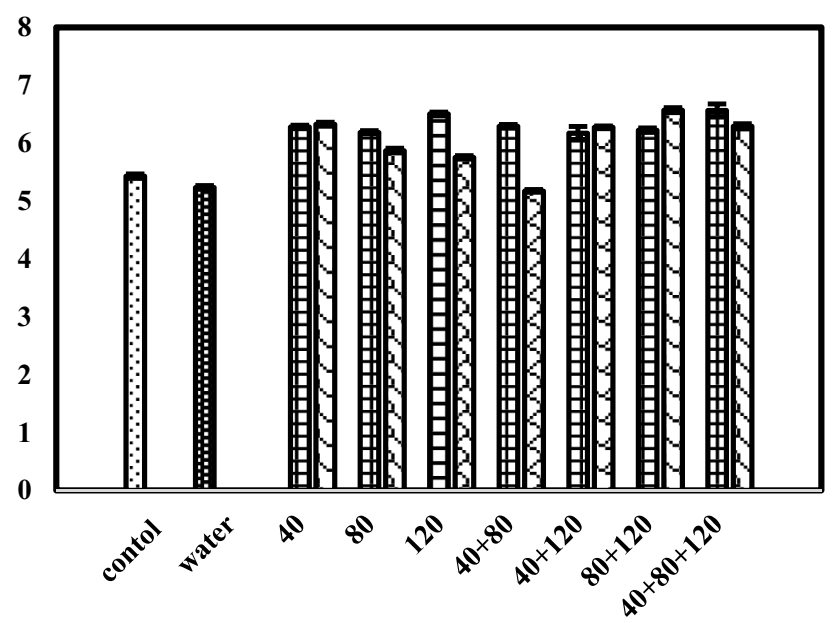

- $\mathbf{m}$ mle 10 凹mle 20

Figure 3. Peroxidase value (meq kg ${ }^{-1}$ ) of black cumin as affected by moringa leaf extract applied at various growth stages.

and their interaction had significant $(\mathrm{P} \leq 0.05)$ variation in peroxidase value of black cumin. Similarly, when means were compared, that of control vs treatments and water spray check vs treatments were found significant for peroxidase value (\%). Mean value of data indicated that highest peroxidase value $(6.32 \%)$ was recorded in $20 \%$ moringa leaf extract treated plots, followed by (6.03\%) $10 \%$ moringa leaf extract. While in case of application stages, highest peroxidase value $(6.42 \%)$ was recorded when moringa leaf extract was applied at stage- 7 $(40+80+120$ days after sowing), followed by $(6.39 \%)$ stage- $6(80+120$ days after sowing). Whereas lowest per- 


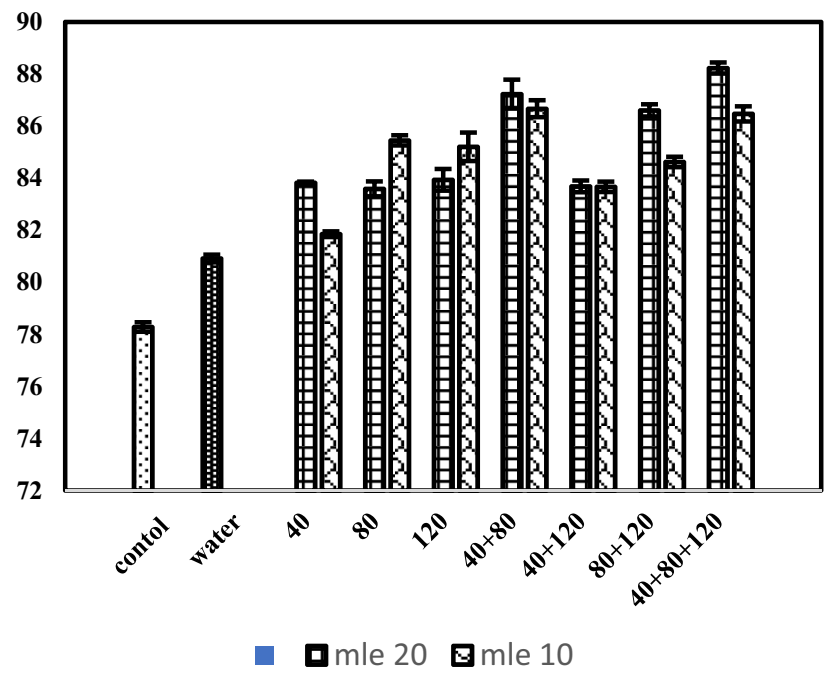

Figure 4. Iodine value (meq $\mathrm{kg}^{-1}$ ) of black cumin as affected by moringa leaf extract applied at various growth stages.

oxidase value (5.73\%) was recorded in plots treated with moringa leaf extract at stage-3 (120 days after sowing). Interaction of moringa leaf extract concentrations and stage of application in Fig. 3 showed that increasing moringa leaf extract concentration from 10 to $20 \%$ applied at growth stage- 7 increased peroxidase value of black cumin crop. However, application of moringa leaf extract @ 10\% applied at growth stage-3 (120 days after sowing) showed lowest peroxidase value. The phytohormones affect the pathway of terpenoids through motivating the responsible physiological and biochemical processes ${ }^{28}$. Our results are in agreement with the reports of Ali et al. ${ }^{27}$ in geranium and Abdel-Rahman and Abdel-Kader ${ }^{30}$ in fennel who observed that MLE application improves both the volatile oil yield and its components. The fact that MLE application improved black cumin growth and quality characters suorts the study's hypothesis that MLE is an important plant growth enhancer. In agreement with our results, Rady and Mohamed ${ }^{28}$ concluded that MLE is considered one of the important plant bio stimulants because it contains antioxidants, phenols, basic nutrients, ascorbates, and phytohormones. Furthermore, foliar application of moringa leaf extract may have a positive effect on endogenous phytohormone concentrations, resulting in improved plant growth and quality ${ }^{10,37}$.

lodine value ( $\mathbf{g}$ of $\mathrm{I}_{\mathbf{2}} / \mathbf{1 0 0} \mathrm{g}$ ). Data concerning iodine value of black cumin oil in response to various concentrations of MLE applied at various growth stages is given in Table 2 and Fig. 4. Statistical analysis of data indicated that both the concentrations of moringa leaf extract, stage of application as well as their interaction had significant effect on iodine value of black cumin oil. The planned mean comparison of control vs rest and water spray vs rest treatments had significant effect on iodine value. Highest iodine value (85.3) was recorded with application of moringa leaf extract @ 20\% whereas, lowest (78.28) was observed in control. Regarding the stage of application, highest iodine value (87.35) was observed in plots sprayed with moringa leaf extract at stage-7 $(40+80+120$ days after sowing), followed by (85.61) plots sprayed with moringa leaf extract at growth stage- 6 $(80+120$ days after sowing). Concerning the interaction of MLE concentrations and stage of application of MLE, highest iodine value (6.49) was observed with $20 \%$ moringa leaf extract sprayed at stage-7 $(40+80+120$ days after sowing) whereas, lowest iodine value was observed in plants sprayed with moringa leaf extract @ 20\% applied at stage-3 (120 days after sowing). The use of plant growth regulators is very specific and depends to achieve specific results like for example; enhanced plant growth, betterment in yield and yield related attributes, and to modify the fruit and plant bio-constituents. Several previous studies reveled that MLE are enriched with many phtyo-hormones especially zeatin ${ }^{31}$. In addition to that MLEs are embedded with many essential amino acids, vitamins $\left(A, B_{1}, B_{2}, B_{3}, C\right.$ and $\left.E\right)$, minerals as well as several antioxidants like phenolic ${ }^{32,33}$. This unique biochemical composition of MLE showed that they can be utilized as bio stimulant which have the potential to promote crop growth, productivity as well as quality which in return depends on its application time ${ }^{34}$.

Total free amino acids. The data presented in Table 2 revealed that moringa leaf extract concentrations and application stages had significantly affected total free amino acid content of black cumin crop during rabi 2019-20 under agro-climatic conditions of Haripur whereas, their interaction remained non-significant. The planned mean comparison of control vs rest and water spray vs rest had significant effect on total free amino acids of black cumin. Highest amino acids (336.3) were observed with the application of moringa leaf extract @ 20\%, followed by application of moringa leaf extract @ 10\%. Regarding application stages, highest total free amino acids (364.2) were observed with the application of moringa leaf extract at $40+80+120$ days after sowing, followed by (355.9) application of MLE at 40+80 days after sowing. Lowest total free amino acids (290.3) were recorded with moringa leaf extract sprayed at 40 days after sowing. Several investigations have demonstrated that MLE can alter both primary and secondary metabolism, resulting in an increase in antioxidant mol- 
ecule concentrations $s^{35,36}$. The content of phenolic antioxidants, total soluble proteins, and total free amino acids increased in spinach plants treated with synthetic growth regulators and MLE ${ }^{26}$. MLE can also increase fruit quality metrics in 'Kinnow' mandarins, such as soluble solid contents, vitamin C, sugars, total antioxidant, phenolic contents, and superoxide dismutase and catalase enzyme activities, when treated at various growth stages ${ }^{37}$.

Total phenolic. Phenolic have acquired much importance because of their properties of disease preventing and health promoting. The effect of moringa leaf extract concentrations, stage of application and their interaction is presented in Table 2. Analysis of variance revealed that moringa leaf extract concentrations and stage of application of moringa leaf extract had significant effect on total phenolic content of black cumin while their interaction remained non-significant. Our results depict that all MLE levels enhanced the total phenolic content of black cumin leaves relative to the control. Highest phenolic content $\left(71.59 \mathrm{mg} \mathrm{g}^{-1}\right)$ was observed with application of moringa leaf extract at the rate of $20 \%$, followed by $\left(68.72 \mathrm{mg} \mathrm{g}^{-1}\right)$ moringa leaf extract application at the rate of $10 \%$. Regarding application stages, highest phenolic content $\left(81.23 \mathrm{mg} \mathrm{g}^{-1}\right)$ was observed with the application of moringa leaf extract at growth stage-7 $\left(40+80+120\right.$ days after sowing), followed by $\left(76.66 \mathrm{mg} \mathrm{g}^{-1}\right)$ stage-6 $\left(80+120\right.$ days after sowing), whereas, lowest phenolic content $\left(55.25 \mathrm{mg} \mathrm{g}^{-1}\right)$ was observed in crop sprayed with moringa leaf extract at stage-3 (120 days after sowing). In the medicinal, biological, and agricultural areas, phenolic and their derivatives gained scientists attention. Recent studies had focused on their potential as antioxidant-rich natural chemicals ${ }^{38}$. The increased content of phenolics, flavonoids, and phytohormones in moringa leaves, which may have contributed to the enhanced total phenolic content in black cumin leaves, can be linked to the higher content of phenolics, flavonoids, and phytohormones in MLE treated plants ${ }^{26}$. Furthermore, the proper concentrations of minerals, vitamins, and -carotene found in moringa leaves may have influenced metabolic processes in a way that increased the internal phenolic content in black cumin leaves, either directly or indirectly ${ }^{39}$. Therefore, these aspects assist MLE to serve as growth enhancer and natural antioxidant ${ }^{40}$. Our results supported by the previous report of Nasir et al. ${ }^{37}$ who revealed that the total phenolic content was enhanced as a result of MLE application at critical stages of plant growth.

\section{Materials and methods}

A field experiment was carried out during 2019-2020. The treatments were arranged in RCB design with factorial arrangements and replicated three times. Size of plots were kept $2.7 \times 1.5 \mathrm{~m}^{2}$. Uniform and normal agronomic practices were kept for all the treatments throughout the study.

Source of moringa leaves. Moring leaves and branches were harvested from fully grown and mature Moringa trees planted at Horticulture Nursery, The University of Haripur.

Preparation of MLE. Stock solution of MLE was made by the method described by Price ${ }^{41}$. Plant material was grinded with the help of locally fabricated extraction machine, for extraction $1 \mathrm{~L}$ of water is added to $10 \mathrm{~kg}$ of plant material. After extraction whole mixture was sieved through a cheese cloth to purify the stock solution of MLE. This stock was further diluted with water (distilled) to make several concentrations for foliar spray.

Observations on the crop. Plant height $(\mathrm{cm})$. Plant height at first flowering was measured when the selected plants for data collection from each plot at maturity.

Number of branches plant ${ }^{-1}$. The total number of branches from ten randomly chosen plants was counted at harvest time and average number of branches plant ${ }^{-1}$ was calculated.

Total free amino acids. Moore and Stein ${ }^{42}$ method was used for the determination of total free amino acids. In $10 \mathrm{~mL}$ of citrate buffer, fresh leaves $(0.5 \mathrm{~g})$ were homogenized ( $\mathrm{pH} 5.0)$. The mixture was then centrifuged for $10 \mathrm{~min}$ at $15,000 \times \mathrm{g}$. The solution's optical density was measured at $570 \mathrm{~nm}$ using a spectrophotometer (UnicoUV 2100 Japan).

Total phenolics. Julkunen-Tiitto ${ }^{43}$ method was used for the determination of total phenolic. With $2.5 \mathrm{~mL}$ of the Folin Ciocalteau reagent (10\%), $1 \mathrm{~mL}$ of diluted extracts was oxidized, followed by neutralization with $2 \mathrm{~mL}$ of sodium carbonate (7.5\%). The mixture was kept dark for $45 \mathrm{~min}$ and the absorption was measured using a spectrophotometer (Unico-UV 2100 Japan) at a wavelength of $765 \mathrm{~nm}$. Gallic acid was used as standard.

Essential oil content (\%). Essential oil content of was determined by following Stainier ${ }^{15}$ method. Oil from hundred grams of crushed Kalonji seeds were extracted using hydro-distillation in $0.5 \mathrm{~L}$ distilled water for $3 \mathrm{~h}$.

Fixed oil ratio (\%). Four grams of powdered Kalonji seeds sample were extracted with $n$-hexane for 6 h using soxlet aaratus for determining the fixed oil content (\%).

Peroxide value $\left(\mathrm{meq} \mathrm{kg}^{-1}\right)$. The peroxide values were calculated by the method of Jacob ${ }^{16} 0.5 \mathrm{~g}$ of black cumin oil was added to mixture of glacial acetic acid and chloroform $(60 \%+40 \%$ respectively). This solution was reacted with potassium iodide solution $(0.5 \mathrm{~mL})$ in a glass store flask. Later on this solution was mixed for $2 \mathrm{~min}$ on a shaker, after shaking $30 \mathrm{~mL}$ of distilled water was added and iodine obtained was treated with $0.01 \mathrm{~N}$ 
sodium thiosulfate by using starch solution as indicator. Then following formula was used to calculate peroxide and expressed as mille moles per $\mathrm{kg}$ oil.

$$
\text { Peroxide value }=\frac{0.5 \times \mathrm{N} \times \mathrm{V} \times 100}{\text { Weight of sample }}
$$

where $\mathrm{N}=$ Normality of sodium thiosulfate solution $\mathrm{V}=$ Volume in $\mathrm{mL}$ of sodium thiosulfate needed for titration.

Iodine value $\left(\mathrm{g}\right.$ of $\mathrm{I}_{2} / 100 \mathrm{~g}$ ). The unsaturation of black cumin oil was obtained by calculating the total amount of halogen absorption by oil as mentioned by Shantha and Decker ${ }^{44} .0 .1-0.5 \mathrm{~g}$ of oil was added to mixture of chloroform $(10 \mathrm{~mL})$ and Hanus iodine $(25 \mathrm{~mL})$ solution and left for $30 \mathrm{~min}$. after that $15 \%$ potassium iodine solution $(10 \mathrm{~mL})$ and freshly boiled and cooled distilled water $(100 \mathrm{~mL})$ was added to the mixture. Liberated iodine was titrated with $0.1 \mathrm{~N}$ of sodium thiosulfate using starch indicator.

$$
\text { Iodine value }=\frac{(\mathrm{V} 1-\mathrm{V} 2) \times \mathrm{N} \times 12.69}{\text { Weight of sample }}
$$

where $\mathrm{N}=$ Normality of sodium thiosulfate solution $\mathrm{V} 1$ = Volume in $\mathrm{mL}$ of sodium thiosulfate needed for titration Blank V2 = Volume in $\mathrm{mL}$ of sod. Thiosulfate needed for titration sample.

Statistical analysis. The treatments mean comparison were made using least significant differences test for significant parameters at $0.05 \%$ level of probability where $\mathrm{p}$ values are significant (Gomez and Gomez ${ }^{45}$ ).

Complies with international, national and/or institutional guidelines. Experimental research and field studies on plants (either cultivated or wild), comply with relevant institutional, national, and international guidelines and legislation. Experimental studies were carried out in accordance with relevant institutional, national or international guidelines or regulation.

Identification of the plant material. Before collection, the plant was identified by Dr. Hanif Khan (Taxonomist), using the standard protocol at the Department of Soil Science, Agricultural University, Peshawar, Pakistan.

Ethics approval and consent to participate. We all declare that manuscripts reporting studies do not involve any human participants, human data, or human tissue. So, it is not applicable.

Received: 17 September 2021; Accepted: 7 December 2021

Published online: 20 December 2021

\section{References}

1. Ramadan, M. F. (ed.) Black Cumin (Nigella sativa) Seeds: Chemistry, Technology, Functionality, and Applications (Springer Nature, 2020). https://doi.org/10.1007/978-3-030-48798-0.

2. Tuasha, N., Petros, B. \& Asfaw, Z. Medicinal plants used by traditional healers to treat malignancies and other human ailments in Dalle District, Sidama Zone, Ethiopia. J. Ethnobiol. Ethnomed. 14(1), 1-21. https://doi.org/10.1186/s13002-018-0213-z (2018).

3. Mehmood, A. et al. Phytochemical screening and antibacterial efficacy of black cumin (Nigella sativa L.) seeds. FUUAST J. Biol. 11(1), 23-28 (2021).

4. Abdel-Hamed, E. M. W. Effect of cultivation, fertilization and irrigation practices on Nigella sativa yield and quality. In Black Cumin (Nigella sativa) Seeds: Chemistry, Technology, Functionality, and Applications 11-21 (Springer, 2021). https://doi.org/10. 1007/978-3-030-48798-0_2.

5. Siddiqui, S. et al. Virtual screening of phytoconstituents from miracle herb nigella sativa targeting nucleocapsid protein and papain-like protease of SARS-CoV-2 for COVID-19 treatment. J. Biomol. Struct. Dyn. https://doi.org/10.1080/07391102.2020. 1852117 (2020).

6. Shahzad, Q. et al. Phytochemical analysis and antimicrobial activity of adhatoda vasica leaves. Pure Appl. Biol. 9(2), 1654-1661. https://doi.org/10.19045/bspab.2020.90174 (2020).

7. Kiralan, M., Kiralan, S. S., Ozkan, G. \& Ramadan, M. F. Composition and functionality of Nigella sativa fixed oil. In Black Cumin (Nigella sativa) Seeds: Chemistry, Technology, Functionality, and Applications 319-333 (Springer, 2021). https://doi.org/10.1007/ 978-3-030-48798-0_20.

8. El-Tahir, K. E. D. H. \& Bakeet, D. M. The black seed Nigella sativa Linnaeus-A mine for multi cures: A plea for urgent clinical evaluation of its volatile oil. J. Taibah Univ. Med. Sci. 1(1), 1-19. https://doi.org/10.1016/S1658-3612(06)70003-8 (2006).

9. Khan, N. et al. Role of sugars, amino acids and organic acids in improving plant abiotic stress tolerance. Pak. J. Bot. 52(2), 355-363 (2020).

10. Gilani, M. et al. Mitigation of drought stress in spinach using individual and combined applications of salicylic acid and potassium. Pak. J. Bot. 52(5), 1505-1513 (2020).

11. Desoky, E. S. M., Elrys, A. S. \& Rady, M. M. Integrative moringa and licorice extracts application improves Capsicum annuum fruit yield and declines its contaminant contents on a heavy metals-contaminated saline soil. Ecotoxicol. Environ. Saf. 169, 50-60. https://doi.org/10.1016/j.ecoenv.2018.10.117 (2019).

12. Elrys, A. S. et al. Mitigate nitrate contamination in potato tubers and increase nitrogen recovery by combining dicyandiamide, moringa oil and zeolite with nitrogen fertilizer. Ecotoxicol. Environ. Saf. 209, 111839. https://doi.org/10.1016/j.ecoenv.2020.111839 (2021).

13. Alaraidh, I. A. Exogenous application of salicylic acid, indoleacetic acid and tryptophan protects growth, chlorophyll synthesis and antioxidant activities and gene expression in Catharanthus roseus. Pak. J. Bot. 52(3), 893-900 (2020).

14. Abbas, R. N. et al. Maize (Zea mays L.) germination, growth and yield response to foliar application of Moringa oleifera Lam. leaf extracts. Crop Environ. 4(1), 39-45 (2013). 
15. Foidle, N., Makkar, H. P. S. \& Becker, K. The potential of Moringa oleifera for agricultural and industrial uses. The miracle Tree: The multiple Attributes of Moringa, pp. 45-76 (2001).

16. Mahmood, K. T., Mugal, T. \& Haq, I. U. Moringa oleifera: A natural gift-a review. J. Pharm. Sci. Res. 2(11), 775 (2010).

17. Anyaegbu, P. O. Comparative evaluation of effects of leaf extracts of selected fallow species and NPK (15: 15: 15) fertilizer on the performance of okra, Abelmoschus esculentus in Abuja, Nigeria. Rep. Opin. 7(10), 39-46 (2015).

18. Manzoor, M. et al. Potential of Moringa (Moringa oleifera: Moringaceae) as plant growth regulator and bio-pesticide against wheat aphids on wheat crop (Triticum aestivum; Poaceae). J. Biopestic. 8(2), 120 (2015).

19. Jain, P., Farooq, B., Lamba, S. \& Koul, B. Foliar spray of Moringa oleifera Lam. leaf extracts (MLE) enhances the stevioside, zeatin and mineral contents in Stevia rebaudiana Betoni. South Afr. J. Bot. 132, 249-257. https://doi.org/10.1016/j.sajb.2020.03.026 (2020).

20. Anjum, S. A. et al. Brassinolide application improves the drought tolerance in maize through modulation of enzymatic antioxidants and leaf gas exchange. J. Agron. Crop Sci. 197(3), 177-185. https://doi.org/10.1111/j.1439-037X.2010.00459.x (2011).

21. Hassanpouraghdam, M. B., El, E. S. M. S. M. \& Mazid, M. Note on the enzyme activities, productivity and quality parameters of chickpea cultivars under influence of diverse synthetic plant growth promoters. Indian J. Agric. Res. 49, 4 (2015).

22. Sakr, W. R., El-Sayed, A. A., Hammouda, A. M. \& Saad El Deen, F. S. A. Effect of NPK, aloe gel and moringa extracts on geranium plants. Int. J. Hortic. Sci. Ornam. Plants 10, 01-16. https://doi.org/10.5829/idosi.jhsop.2018.01.16 (2018).

23. Rady, M. M., Varma, B. \& Howladar, S. M. Common bean (Phaseolus vulgaris L.) seedlings overcome $\mathrm{NaCl}$ stress as a result of presoaking in Moringa oleifera leaf extract. Sci. Hortic. 162, 63-70. https://doi.org/10.1016/j.scienta.2013.07.046 (2013).

24. Prabhu, M., Kumar, A. R. \& Rajamani, K. Influence of different organic substances on growth and herb yield of sacred basil (Ocimum sanctum L.). Indian J. Agric. Res. 44(1), 48-52 (2010).

25. Mazrou, R. M. Moringa leaf extract application as a natural biostimulant improves the volatile oil content, radical scavenging activity and total phenolics of coriander. J. Med. Plant Stud. 7, 45-51 (2019).

26. Aslam, M., Sultana, B., Anwar, F. \& Munir, H. Foliar spray of selected plant growth regulators affected the biochemical and antioxidant attributes of spinach in a field experiment. Turk. J. Agric. For. 40(2), 136-145. https://doi.org/10.3906/tar-1412-56 (2016).

27. Ali, E. F., Hassan, F. A. S. \& Elgimabi, M. Improving the growth, yield and volatile oil content of Pelargonium graveolens L. Herit by foliar application with moringa leaf extract through motivating physiological and biochemical parameters. South Afr. J. Bot. 119, 383-389. https://doi.org/10.1016/j.sajb.2018.10.003 (2018).

28. Bano, U. et al. Effect of plant growth regulators on essential oil yield in aromatic plants. J. Chem. Pharm. Res. 8(7), 733-739 (2016).

29. Ali, Z., Basra, S. M. A., Munir, H. A. S. S. A. N., Mahmood, A. \& Yousaf, S. Mitigation of drought stress in maize by natural and synthetic growth promoters. J. Agric. Soc. Sci. 7(2), 56-62 (2011).

30. Abdel-Rahman, S. S. A. \& Abdel-Kader, A. A. S. Response of Fennel (Foeniculum vulgare, Mill) plants to foliar application of moringa leaf extract and benzyladenine (BA). South Afr. J. Bot. 129, 113-122. https://doi.org/10.1016/j.sajb.2019.01.037 (2020).

31. Rady, M. M. \& Mohamed, G. F. Modulation of salt stress effects on the growth, physio-chemical attributes and yields of Phaseolus vulgaris L. plants by the combined application of salicylic acid and Moringa oleifera leaf extract. Sci. Hortic. 193, 105-113. https:// doi.org/10.1016/j.scienta.2015.07.003 (2015).

32. Howladar, S. M. A novel Moringa oleifera leaf extract can mitigate the stress effects of salinity and cadmium in bean (Phaseolus vulgaris L.) plants. Ecotoxicol. Environ. Saf. 100, 69-75. https://doi.org/10.1016/i.ecoenv.2013.11.022 (2014).

33. El Sohaimy, S. A., Hamad, G. M., Mohamed, S. E., Amar, M. H. \& Al-Hindi, R. R. Biochemical and functional properties of Moringa oleifera leaves and their potential as a functional food. Glob. Adv. Res. J. Agric. Sci. 4(4), 188-199 (2015).

34. Basra, S. M. A., Iftikhar, M. N. \& Afzal, I. Potential of moringa (Moringa oleifera) leaf extract as priming agent for hybrid maize seeds. Int. J. Agric. Biol. 13, 6 (2011).

35. Latif, H. H. \& Mohamed, H. I. Exogenous applications of moringa leaf extract effect on retrotransposon, ultrastructural and biochemical contents of common bean plants under environmental stresses. South Afr. J. Bot. 106, 221-231 (2016)

36. Ashraf, R., Sultana, B., Iqbal, M. \& Mushtaq, M. Variation in biochemical and antioxidant attributes of Raphanus sativus in response to foliar application of plant leaf extracts as plant growth regulator. J. Genet. Eng. Biotechnol. 14(1), 1-8 (2016).

37. Nasir, M., Khan, A. S., Basra, S. A. \& Malik, A. U. Foliar application of moringa leaf extract, potassium and zinc influence yield and fruit quality of 'Kinnow'mandarin. Sci. Hortic. 210, 227-235 (2016).

38. Saxena, M., Saxena, J. \& Pradhan, A. Flavonoids and phenolic acids as antioxidants in plants and human health. Int. J. Pharm. Sci. Rev. Res. 16(2), 130-134 (2012).

39. Jacob, S. J. P. \& Shenbagaraman, S. Evaluation of antioxidant and antimicrobial activities of the selected green leafy vegetables. Int. J. Pharm. Tech. Res. 3(1), 148-152 (2011).

40. Singh, H. P., Batish, D. R., Setia, N. \& Kohli, R. K. Herbicidal activity of volatile oils from Eucalyptus citriodora against Parthenium hysterophorus. Ann. Appl. Biol. 146(1), 89-94 (2005).

41. Price, M. L. The moringa tree. ECHO Tech. Note 17391, 1-19 (2007).

42. Moore, S. \& Stein, W. H. A modified ninhydrin reagent for the photometric determination of amino acids and related compounds. J. Biol. Chem. 211(2), 907-913 (1954).

43. Julkunen-Tiitto, R. Phenolic constituents in the leaves of northern willows: Methods for the analysis of certain phenolics. J. Agric. Food Chem. 33(2), 213-217. https://doi.org/10.1021/jf00062a013 (1985).

44. Shantha, N. C. \& Decker, E. A. Rapid, sensitive, iron-based spectrophotometric methods for determination of peroxide values of food lipids. J. AOAC Int. 77(2), 421-424 (1994).

45. Gomez, K. A., Gomez, K. A. \& Gomez, A. A. Statistical Procedures for Agricultural Research (Wiley, 1984).

\section{Acknowledgements}

The authors would like to extend their sincere appreciation to the Researchers Supporting Project number (RSP2021/347), King Saud University, Riyadh, Saudi Arabia.

\section{Author contributions}

Conceptualization, S.F.; data curation, K.N., Q.A.; formal analysis, S.A., M.H.S., C.W., D.W.; investigation, A.M.; methodology, S.S.; project administration, J.B.; resources, S.D., R.D.; supervision, S.F.; validation, H.M.H., W.N., M.M.; writing_original draft, F.S., K.N.; writing_review and editing, S.F.

\section{Funding}

Researchers Supporting Project number (RSP-2021/347), King Saud University, Riyadh, Saudi Arabia.

\section{Competing interests}

The authors declare no competing interests. 


\section{Additional information}

Correspondence and requests for materials should be addressed to A.M., S.S. or S.F.

Reprints and permissions information is available at www.nature.com/reprints.

Publisher's note Springer Nature remains neutral with regard to jurisdictional claims in published maps and institutional affiliations.

(c) (1) Open Access This article is licensed under a Creative Commons Attribution 4.0 International License, which permits use, sharing, adaptation, distribution and reproduction in any medium or format, as long as you give appropriate credit to the original author(s) and the source, provide a link to the Creative Commons licence, and indicate if changes were made. The images or other third party material in this article are included in the article's Creative Commons licence, unless indicated otherwise in a credit line to the material. If material is not included in the article's Creative Commons licence and your intended use is not permitted by statutory regulation or exceeds the permitted use, you will need to obtain permission directly from the copyright holder. To view a copy of this licence, visit http://creativecommons.org/licenses/by/4.0/.

(C) The Author(s) 2021 